\title{
Synthesis and Pain Inhibition Activity of the Analogs of 1-Allyl-3-Benzoylthiourea for New Analgesic Lead Compound Discovery
}

\author{
Alvan F. Shalas ${ }^{1, *}$, Siswandono ${ }^{2}$, Marcellino Rudyanto ${ }^{2}$ \\ 'Departement of Pharmacy, Faculty of Medicine, Brawijaya University, Jl. Veteran, Malang, INDONESIA. \\ 2Faculty of Pharmacy, Airlangga University, Jl. Dharmawangsa, Surabaya, INDONESIA.
}

\begin{abstract}
Objective: The study aimed to synthesize four analogs of 1-allyl-3-benzoylthiourea ( $\mathrm{R}=\mathrm{H}$; $2-\mathrm{Cl} ; 3-\mathrm{Cl}$; and $4-\mathrm{Cl})$, and evaluate their pain inhibition activities. Method: The chemical structure was drawn assisted by ChemDraw Ultra 8.0 and Chem3D Ultra 8.0 software. Molegro Virtual Docker 5.0 software was utilized for the docking process, to determine the interaction energy values between compounds of interest and the COX-2 receptor (PDB: 1PXX). The synthesis step was done by nucleophilic substitution (benzoylation) on allylthiourea compound via modified Schotten-Baumann reaction. Chemical structure analysis was evaluated by means of Infra-Red, Nuclear Magnetic Resonance, and Mass Spectroscopy methods. The pain inhibition assay was done using acetic acid induced writhing test, using mice (Mus musculus) as animal model. Results: Preliminary in silico screening showed that all four candidate compounds possessed good interaction on COX-2 receptor. The synthesis process produced rendemen of the compounds vary between $15.2 \%-47 \%$. Chemical structure evaluation confirmed the structural match of the products as expected. Acetic acid induced writhing test in mice (Mus musculus) showed that three compounds possessed a better pain inhibition activity compared to positive control diclofenac sodium. Conclusion: 1-allyl-3-benzoylthiourea analogs
\end{abstract}

showed good pain inhibition activity. The compounds can serve as leads for analgesic activity through the inhibition of COX-2.

Keywords: Synthesis; 1-allyl-3-benzoylthiourea; COX-2; Analgesic; Lead Compound;

Key Message: Thiourea compounds have been known for their vary pharmacological activites. The novelty of this research is the compounds that are synthesized in search of analgesic lead compound. Additionally, the results showed that the compounds possessed good pain inhibition activity, and need to be developed further.

\section{Correspondence:}

Alvan F. Shalas, Department of Pharmacy, Faculty of Medicine, Brawijaya University, INDONESIA.

Phone: +6285258898373

Email: alvanshalas@gmail.com

DOI: $10.5530 /$ jyp.2018.10.4

\section{INTRODUCTION}

Pain and the efforts to relieve or overcome it have been a problem for human being since ancient times. The isolation of the opioid in third millennium B.C by the Sumerian, usage of willow bark in the $8^{\text {th }}$ century, to the modern salicylates synthesis highlights our endeavor to fight the pain. The new age of modern analgesic discovery is started since the finding of opioid receptor and endogenic substances possessed pain reducing activity. ${ }^{1,2}$ Since the 1960 s to 2010 there are 59 agents identified as analgesic and are still being used today. Despite the large number of analgesic drugs, the problems associated with analgesics remain challenging, thus the discovery of new agents has always been a focus of significant effort and investment. ${ }^{3,4}$ Significant gastrointestinal complications like peptic ulcer, perforation, and bleeding have limited clinical use of oftenly prescribed NSAIDs (Non-Steroidal Anti-inflammatory Drugs), meanwhile selective COX-2 inhibitors adverse events on cardiovascular need important consideration. Narcotic analgesics are associated with problems such as social abuse and other side effects like psychological dependency, addiction, tolerance, sedation, constipation, and respiratory depression. ${ }^{5-8}$

Thiourea derivatives have been reported for their wide biological activities, which are antidepressant, antimicrobial, anticancer, antioxidant, antiinflammatory, and analgesic activity., ${ }^{9,11,12,13}$ A work by our colleagues to investigate analgesic and anti-inflammatory activity on analogs of benzoylthiourea showed that benzoylthiourea possessed better analge- sic activity compared to diclofenac sodium, with pain inhibition values $(12.5 \mathrm{mg} / \mathrm{kgBW}$ dose; $\mathrm{t}=30 \mathrm{~min})$ were $42.59 \% \pm 12.33$ and $34.71 \% \pm 9.85$ respectively. Halogen group addition on the aromatic ring (i.e. 4-chlorobenzoylthiourea) affects the pain inhibition activity to an even better value, which was $82.10 \% \pm 8.96 .{ }^{14}$ Improvement of desirable properties (i.e. biological activity) of a compound by structure modification can be done by several strategies, among them are homologation and substitution of an aromatic ring. Alteration of the size and or shape of an alkyl substituent can affect the conformational preference of a flexible molecule and may alter the spatial relationships of the components of the pharmacophore. The alkyl group itself may represent a binding site with the receptor (through hydrophobic interactions), and alteration of the chain may alter its binding capacity. Position isomers of substituents on an aromatic ring may possess different pharmacological properties. In addition to their ability to affect electron distribution over an aromatic ring system, position isomers may differ in their complementarity to receptors, and the position of a substituent on a ring may influence the spatial occupancy of the ring system. ${ }^{15}$

This work represents our effort toward the discovery of a new analgesic drug, by the addition of an allyl functional group as well as substituted benzoyl into thiourea pharmacophore structure. We have aimed to synthesize some novel 1-allyl-3-benzoylthiourea analogs (Figure 1), and screened for their pain inhibition activity. 


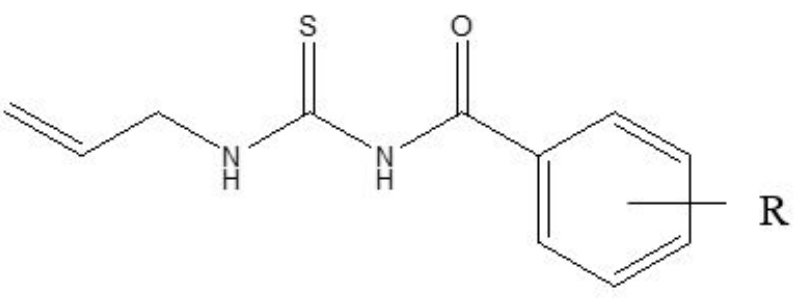

Figure 1: The compounds of interest, 1-allyl-3-benzoylthiourea analogs. $\mathrm{R}=\mathrm{H}$; $2-\mathrm{Cl} ; 3-\mathrm{Cl}$; and $4-\mathrm{Cl}$
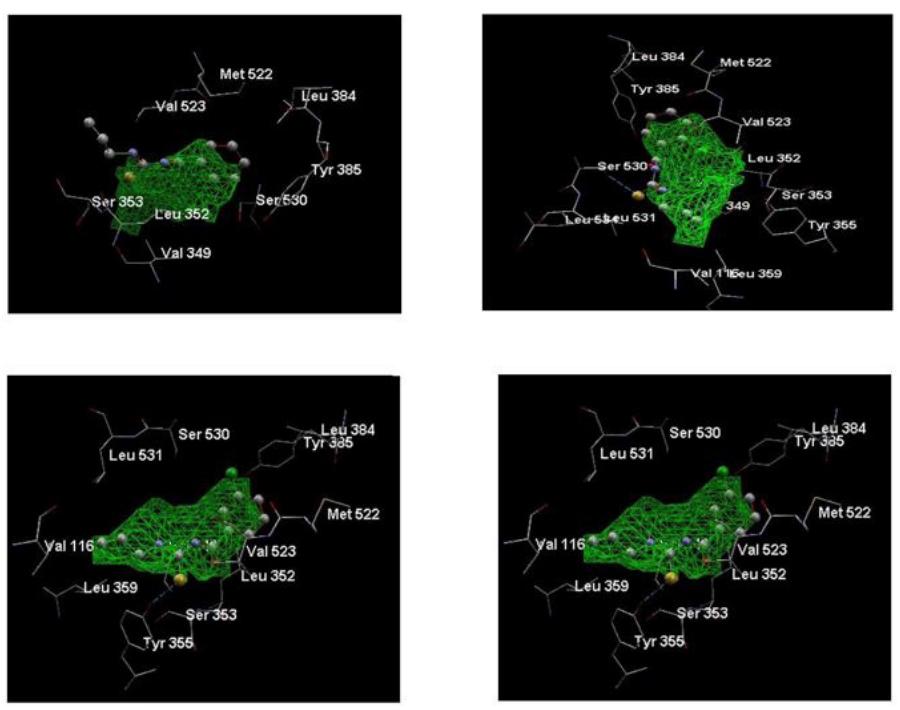

Figure 2: Docked poses of Cpd-a; Cpd-b; Cpd-c; and Cpd-d

\section{MATERIALS AND METHODS}

\section{In silico screening}

We have done a preliminary study by in silico screening to compare the interaction energy of four analogs of 1-allyl-3-benzoylthiourea to benzoylthiourea (previously proven to be active as an analgesic) on COX 2 receptor (PDB: 1PXX). The software ChemDraw Ultra 8.0 and Chem3D Ultra 8.0 were utilized for chemical structure drawing, and docking was done by Molegro Virtual Docker 5.0 software. The rerank scores of each compound are shown in Table 1, while the docked poses view are shown in (Figure 2). Docking study showed that the target compounds possess better affinity compared to benzoylthiourea, from our preliminary study we have concluded that the compounds of interest possessed a better potential than benzoylthiourea, and were valuable to be developed further as analgesic candidate. We have also synthesized 1 of four compounds of interest, which is 1-allyl-3-(2-chlorobenzoyl)thiourea and examined it for the analgesic activity. The result showed that 1-allyl-3-(2-chlorobenzoyl)thiourea possessed better analgesic activity compared to diclofenac sodium. ${ }^{16}$

\section{Chemistry}

Infrared spectra were recorded on FTIR PERKIN ELMER Spectrum One instrument, with $\mathrm{KBr}$ pellet sample preparation method. ${ }^{1} \mathrm{H}$ - and ${ }^{13} \mathrm{C}$-NMR spectra were obtained by means of NMR JEOL ICS $400 \mathrm{MHz}$
Table 1: Re rank Scores of the compounds of interest

\begin{tabular}{ccc}
\hline No & Compound & Rerank Score \\
\hline 1. & Benzoylthiourea & -73.158 \\
2. & Cpd- $a$ & -80.079 \\
3. & Cpd- $b$ & -82.287 \\
4. & Cpd- $c$ & -84.467 \\
5. & Cpd- $d$ & -83.665 \\
\hline
\end{tabular}

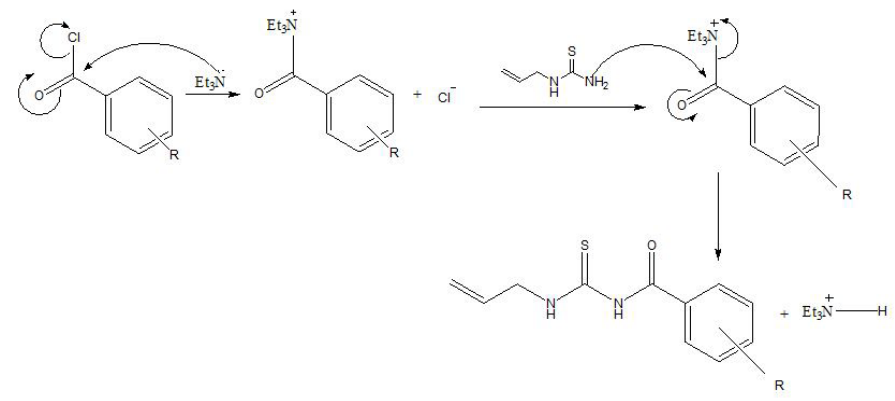

Figure 3: Synthetic scheme of 1-Allyl-3-benzoylthiourea analogs

instrument in chloroform- $d\left(\mathrm{CDCl}_{3}\right)$ solvent, with tetramethylsilane as internal standard. The chemical shift values were recorded on a $\delta$ scale and the coupling constants $(J)$ in hertz. The following abbreviations were used in reporting spectra: $\mathrm{s}=$ singlet, $\mathrm{d}=$ doublet, $\mathrm{t}=$ triplet, $\mathrm{q}=$ quartet, $\mathrm{m}=$ multiplet. The mass spectra were acquired on electron impact mass spectroscopy, recorded on a GC/MS AGILENT 5975C instrument. Electron impact ionization was at $70 \mathrm{eV}$. Purity test was done by Thin Layer Chromatography (TLC) with gel silica $60 \mathrm{GF}_{254}$ (Merck) as stationary phase, and n-hexane: ethylacetate (5:1) solvent system. Chromatograms visualization were done under $254 \mathrm{~nm}$ UV lamp. Melting points range were determined in a capillary using Melt-Temp Electrothermal apparatus. The reactants allylthiourea and benzoylchloride analogs used in the synthesis were obtained from Sigma Aldrich Singapore.

\section{General Procedure for Synthesis of Cpd-a-d}

The synthesis procedure referred to Schotten-Baumann method with some modifications. ${ }^{17}$ A $250 \mathrm{ml}$ round-bottom flask was filled with solution of $0.0172 \mathrm{~mol}$ allylthiourea (Sigma-Aldrich) and $0.028 \mathrm{~mol}$ triethylamine (Merck) in $50 \mathrm{ml}$ tetrahydrofuran (Merck). The solution then put in an ice water bath, and stirred. Each benzoylchloride analogs (benzoylchloride; 2-chlorobenzoylchloride; 3-chlorobenzoylchloride; and 4-chlorobenzoylchloride (Sigma-Aldrich)) as much as $0.0143 \mathrm{~mol}$ was dissolved in $15 \mathrm{ml}$ tetrahydrofuran, and added dropwise to the first solution using dropping funnel over a 30 minutes period. The solution then heated on reflux for 5 hours, allowed cool at room temperature, then vacuum filtered by Buchner funnel. The solvent then removed under reduced pressure. The oil-like consistency product then washed with saturated sodium carbonate solution to solidify the product. Purification was done by recrystallization with hot methanol. Synthesic scheme is given in (Figure 3).

\section{Analgesic Activity Assay}

The pain inhibition assay was done using writhing test method. 6-8 weeks old, 20-30 g BW, 2 weeks adapted, and ad libitum dieted mice (Mus musculus), were divided into three groups: positive control; negative control; and test groups. The test group was devided further into three classes of dose: $6.25 \mathrm{mg} / \mathrm{kgBW} ; 12.5 \mathrm{mg} / \mathrm{kgBW}$; and $25 \mathrm{mg} / \mathrm{kgBW}$. Each group in this assay contains five mice. The negative control mice were 
injected with 1\% CMC-Na suspension, while the positive control mice were injected with $12.5 \mathrm{mg} / \mathrm{kg}$ BW of diclofenac sodium (Dexa Medica, Indonesia) in 1\% CMC-Na suspension. Pain induction was given through $10 \mathrm{ml} / \mathrm{kg}$ BW injection of $1 \%$ acetic acid in CMC-Na suspension. All of the substances were injected intraperitoneally. The ethical clearance of the assay was approved by Airlangga University Animal Care and Use Committee, written on the ethical clearance document no: 501-KE. The amount of writhing movements of mice were observed at the time of five minutes after the pain induction, for 30 minutes periods, Pain Inhibition Percentage (PIP) values then calculated. $\mathrm{ED}_{50}$ values were obtained by probit analysis done by SPSS 20 program.

\section{RESULTS}

\section{In Silico screening}

All four candidate compouds (Cpd- $a-d$ ) showed better interaction on receptor COX-2 (PDB: 1PXX) compared to reference benzoylthiurea compound. The best rerank score was possessed by Cpd-c (-84.467), and followed by Cpd- $d$ (-83.655), Cpd- $b$ (-82.287), and Cpd- $a$ (80.079), while the reran score of the reference compound was -73.158 .

Ligand map interaction showed the presence of hydrogen bonding on Cpd $b$ to ser530 moiety of the receptor. The hydrogen bonding also noticed in Cpd- $c$ and Cpd- $d$ interacting to receptors tyr355. Meanwhile Cpd- $a$ interacting with the receptor by steric interaction to Tyr385, Ser353, Leu352, Val523, and Met522 moiety.

\section{Synthesis}

All four synthesized compounds were pure, the TLC chromatograms showed a single spot, and melting point assay showed less than $2^{\circ} \mathrm{C}$ melting point range for each compound.

1-Allyl-3-benzoylthiourea (Cpd-a). colorless crystal. Yield 47\%. mp 64-65 ${ }^{0}$ C. TLC Rf: 0.68. IR $v \mathrm{~cm}^{-1}: 3466$ (O-H iminol); 1669 (C=C- vinylic); $1547(\mathrm{C}=\mathrm{O}) ; 1531(\mathrm{C}=\mathrm{S}) ; 1179(\mathrm{C}-\mathrm{N}) .{ }^{1} \mathrm{H}-\mathrm{NMR}\left(400 \mathrm{MHz} ; \mathrm{CDCl}_{3}\right) \delta$ (ppm): 10.78 (s, 1H, CONH); $9.04(\mathrm{~s}, 1 \mathrm{H}, \mathrm{NH}) ; 7.81(\mathrm{~d}, J=7.2 \mathrm{~Hz}, 2 \mathrm{H}$, Ar- $H$ ); 7.60 (t, $J=7.6 \mathrm{~Hz}, 2 \mathrm{H}, \mathrm{Ar}-H) ; 7.48$ (t, $J=7.6 \mathrm{~Hz}, 2 \mathrm{H}, \mathrm{Ar}-H) ; 5.95$ (ddt, $J=17.2,10.4,6.4 \mathrm{~Hz}, 1 \mathrm{H}$, vin- $H$ ); 5.30 (ddt, $J=17.2,1.6,1.2 \mathrm{~Hz}, 1 \mathrm{H}$, vin- $H$ ); 5.23 (ddt, $J=10.4,1.2,1.2 \mathrm{~Hz}, 1 \mathrm{H}$, vin- $H)$; 4.36-4.32 (m, $2 \mathrm{H}$, allylic $H) .{ }^{13} \mathrm{C}-\mathrm{NMR}\left(400 \mathrm{MHz} ; \mathrm{CDCl}_{3}\right) \delta(\mathrm{ppm}): 180.0(\mathrm{C}=\mathrm{S}), 166.8(\mathrm{C}=\mathrm{O})$, $133.5,131.8,131.7,129.1,127.4,117.7,48.0$ (Allylic $C$ ). MS (EI) m/z: $220.1[\mathrm{M}]^{+} ; 105\left[\mathrm{C}_{7} \mathrm{H}_{5} \mathrm{O}\right]^{+} ; 77\left[\mathrm{C}_{6} \mathrm{H}_{5} \mathrm{O}\right]^{+} ; 51\left[\mathrm{C}_{4} \mathrm{H}_{3}\right]^{+}$.

1-Allyl-3-(2-chlorobenzoyl)thiourea (Cpd-b). colorless crystal. Yield 26.2\%. mp 127-128 C. TLC Rf: 0.58. IR $v \mathrm{~cm}^{-1}$ : 3465 (O-H iminol); 1692 (C=C- vinylic); $1556(\mathrm{C}=\mathrm{O}) ; 1538(\mathrm{C}=\mathrm{S}) ; 1179(\mathrm{C}-\mathrm{N}) .{ }^{1} \mathrm{H}-\mathrm{NMR}$ $\left(400 \mathrm{MHz} ; \mathrm{CDCl}_{3}\right) \delta(\mathrm{ppm}): 10.52(\mathrm{~s}, 1 \mathrm{H}, \mathrm{CONH}) ; 9.05(\mathrm{~s}, 1 \mathrm{H}, \mathrm{NH})$; 7.61 (d, $J=6.8 \mathrm{~Hz}, 1 \mathrm{H}, \operatorname{Ar}-H)$; 7.44-7.40 (m, 2H, Ar-H); 7.35-7.30 (m, $1 \mathrm{H}, \operatorname{Ar}-H) ; 5.91$ (ddt, $J=17.4,10.8,6.0 \mathrm{~Hz}, 1 \mathrm{H}$, vin- $H$ ); 5.28 (dd, $J=17.0$, $1.2 \mathrm{~Hz}, 1 \mathrm{H}$, vin- $H$ ); 5.21 (dd, $J=10.4,1.2 \mathrm{~Hz}, 1 \mathrm{H}$, vin- $H)$; 4.30-4.27- (m, $2 \mathrm{H}$, allylic $H) .{ }^{13} \mathrm{C}-\mathrm{NMR}\left(400 \mathrm{MHz} ; \mathrm{CDCl}_{3}\right) \delta(\mathrm{ppm}): 178.8(\mathrm{C}=\mathrm{S}), 165.0$ $(C=\mathrm{O}), 132.0,131.2,130.6,130.0,129.7,129.1,126.4,116.9,47.0$ (Allylic C). MS (EI) m/z: $252.9[\mathrm{M}-\mathrm{H}]^{+} ; 155\left[\mathrm{C}_{7} \mathrm{H}_{6} \mathrm{ClNO}\right]^{+} ; 139\left[\mathrm{C}_{7} \mathrm{H}_{4} \mathrm{ClO}\right]^{+} ; 111$ $\left[\mathrm{C}_{6} \mathrm{H}_{4} \mathrm{Cl}\right]^{+} ; 75\left[\mathrm{C}_{6} \mathrm{H}_{3}\right]^{+}$

1-Allyl-3-(3-chlorobenzoyl)thiourea (Cpd-c). colorless crystal. Yield 16.4\%. mp 69-70 C. TLC Rf: 0.72. IR $v \mathrm{~cm}^{-1}: 3459$ (O-H iminol); 1667 (C=C- vinylic); 1548 (C=O); 1538 (C=S); $1183(\mathrm{C}-\mathrm{N}) .{ }^{1} \mathrm{H}-\mathrm{NMR}(400 \mathrm{MHz}$; $\left.\mathrm{CDCl}_{3}\right) \delta(\mathrm{ppm}): 10.68(\mathrm{~s}, 1 \mathrm{H}, \mathrm{CONH}) ; 9.05(\mathrm{~s}, 1 \mathrm{H}, \mathrm{NH}) ; 7.82(\mathrm{~s}, 1 \mathrm{H}$, $\operatorname{Ar}-H) ; 7.68(\mathrm{~d}, J=8.0 \mathrm{~Hz}, 1 \mathrm{H}, \mathrm{Ar}-H) ; 7.57$ (dd, J=6.8, $0.8 \mathrm{~Hz}, 1 \mathrm{H}, \mathrm{Ar}-H)$; 7.44 (dd, $J=8,7.6 \mathrm{~Hz}, 1 \mathrm{H}$, Ar- $H$ ); 5.93 (ddt, $J=17.2,10.4,5.6 \mathrm{~Hz}, 1 \mathrm{H}$, vin- $H$ ); 5.31 (dd, $J=16.8,0.8 \mathrm{~Hz}, 1 \mathrm{H}$, vin- $H$ ); 5.25 (d, $J=10.4 \mathrm{~Hz}, 1 \mathrm{H}$, vin- $H)$; 4.34-4.31 (m, $2 \mathrm{H}$, allylic $H) .{ }^{13} \mathrm{C}-\mathrm{NMR}\left(400 \mathrm{MHz} ; \mathrm{CDCl}_{3}\right)$ $\delta(\mathrm{ppm}): 178.6(\mathrm{C}=\mathrm{S}), 164.4(\mathrm{C}=\mathrm{O}), 134.4,132.5,132.4,130.5,129.3$, 126.8, 124.2, 116.8, 47.0 (Allylic C). MS (EI) m/z: $252.9[\mathrm{M}-\mathrm{H}]^{+} ; 155$ $\left[\mathrm{C}_{7} \mathrm{H}_{6} \mathrm{ClNO}\right]^{+} ; 139\left[\mathrm{C}_{7} \mathrm{H}_{4} \mathrm{ClO}\right]^{+} ; 111\left[\mathrm{C}_{6} \mathrm{H}_{4} \mathrm{Cl}\right]^{+} ; 75\left[\mathrm{C}_{6} \mathrm{H}_{3}\right]^{+}$

\begin{tabular}{|c|c|c|c|c|}
\hline No & Compound & $\begin{array}{c}\text { Dose (mg/ } \\
\text { kgBW) }\end{array}$ & $\begin{array}{l}\text { Average } \\
\text { Number of } \\
\text { Writhing } \\
\text { Movements }\end{array}$ & $\begin{array}{l}\text { Average Pain } \\
\text { Inhibition } \\
\text { Percentage } \\
\text { (\%) }\end{array}$ \\
\hline 1. & $\begin{array}{l}\text { CMC-Na (Negative } \\
\text { control) }\end{array}$ & & 59.6 & \\
\hline 2. & $\begin{array}{l}\text { Diclofenac Sodium } \\
\text { (Positive control) }\end{array}$ & 12.5 & 40.2 & $32.55 \pm 11.95$ \\
\hline \multirow[t]{3}{*}{3.} & $\begin{array}{c}\text { 1-Allyl-3- } \\
\text { benzoylthiourea }\end{array}$ & 6.25 & 43.2 & $27.52 \pm 8.99$ \\
\hline & & 12.5 & 41.8 & $29.87 \pm 16.07$ \\
\hline & & 25 & 41.2 & $30.87 \pm 5.49$ \\
\hline \multirow[t]{3}{*}{4.} & 1-allyl-3-(2- & 6.25 & 37.4 & $37.25 \pm 9.54$ \\
\hline & & 12.5 & 32.8 & $44.97 \pm 10.70$ \\
\hline & & 25 & 16.6 & $72.15 \pm 12.02$ \\
\hline \multirow[t]{3}{*}{5.} & 1-allyl-3-(3- & 6.25 & 26.2 & $56.04 \pm 8.59$ \\
\hline & & 12.5 & 21.4 & $64.09 \pm 8.77$ \\
\hline & & 25 & 13.8 & $76.85 \pm 3.64$ \\
\hline \multirow[t]{3}{*}{6.} & 1-allyl-3-(4- & 6.25 & 20.4 & $65.77 \pm 3.48$ \\
\hline & & 12.5 & 21.2 & $64.43 \pm 4.01$ \\
\hline & & 25 & 11.6 & $80.54 \pm 6.77$ \\
\hline
\end{tabular}

1-Allyl-3-(4-chlorobenzoyl)thiourea (Cpd-d). colorless crystal. Yield 15.2\%. mp 132-133 ${ }^{\circ} \mathrm{C}$. TLC Rf: 0.81. IR $v \mathrm{~cm}^{-1}: 3466$ (O-H iminol); 1664 (C=C- vinylic); $1547(\mathrm{C}=\mathrm{O}) ; 1178(\mathrm{C}-\mathrm{N}) .{ }^{1} \mathrm{H}-\mathrm{NMR}\left(400 \mathrm{MHz} ; \mathrm{CDCl}_{3}\right) \delta$ (ppm): 10.73 (s, 1H, CONH); 9.07 (s, $1 \mathrm{H}, \mathrm{NH}) ; 7.76(\mathrm{~d}, J=8.8 \mathrm{~Hz}, 2 \mathrm{H}$, Ar- $H$ ); 7.46 (d, $J=8.8 \mathrm{~Hz}, 2 \mathrm{H}, \mathrm{Ar}-H)$; 5.94 (ddt, $J=16.8,10.4,6.0 \mathrm{~Hz}, 1 \mathrm{H}$, vin- $H$ ); 5.30 (d, $J=16.8 \mathrm{~Hz}, 1 \mathrm{H}$, vin- $H$ ); 5.24 (dd, $J=9.6,1.2 \mathrm{~Hz}, 1 \mathrm{H}$, vin- $H$ ); 4.34-4.30 (m, 2H, allylic $H) .{ }^{13} \mathrm{C}-\mathrm{NMR}\left(400 \mathrm{MHz} ; \mathrm{CDCl}_{3}\right) \delta(\mathrm{ppm}): 178.7$ $(C=S), 164.8(C=\mathrm{O}), 139.1,130.6,129.1,128.4,128.0,116.8,47.0$ (Allylic C). MS (EI) m/z: $252.9[\mathrm{M}-\mathrm{H}]^{+} ; 155\left[\mathrm{C}_{7} \mathrm{H}_{6} \mathrm{ClNO}\right]^{+} ; 139\left[\mathrm{C}_{7} \mathrm{H}_{4} \mathrm{ClO}\right]^{+} ; 111$ $\left[\mathrm{C}_{6} \mathrm{H}_{4} \mathrm{Cl}\right]^{+} ; 75\left[\mathrm{C}_{6} \mathrm{H}_{3}\right]^{+}$

\section{Analgesic Activity}

The results showed that compound 1-allyl-3-(2-chlorobenzoyl)thiourea, 1-allyl-3-(3-chlorobenzoyl)thiourea, and 1-allyl-3-(4-chlorobenzoyl) thiourea at all three doses $(6.25,12.5$, and $25 \mathrm{mg} / \mathrm{kgBW})$ possess better pain inhibition activity compared to diclofenac sodium $12.5 \mathrm{mg} / \mathrm{kgBW}$. 1-allyl-3-(4-chlorobenzoyl) thiourea was the strongest pain inhibitor, followed by 1-allyl-3-(3-chlorobenzoyl) thiourea and 1-allyl-3-(2-chlorobenzoyl) thiourea. 1-Allyl-3-benzoylthiourea did not show any better pain inhibition compared to diclofenac sodium. The values of pain inhibition percentage are shown in Table 2.

Probit analysis (SPSS 20) was utilized to determine analgesic median effective dose $\left(\mathrm{ED}_{50}\right)$ values. The result showed that 1-allyl-3-(4-chlorobenzoyl)thiourea possessed the smallest $\mathrm{ED}_{50}$ value, proven to be the strongest analgesic compared to the other three compounds. The $\mathrm{ED}_{50}$ values of the 1-allyl-3-benzoylthiourea; 1-allyl-3-(2-chlorobenzoyl)thiourea; 1-allyl-3-(3-chlorobenzoyl)thiourea; and 1-allyl-3-(4-chlorobenzoyl)thiourea are $33.469 ; 15.440 ; 11.204$; and 9.820 respectively. 
Shalas et al.: 1-allyl-3-benzoylthiurea as Analgesic Lead Compound

\section{DISCUSSION}

The in silico studies was done prior to the synthesis process. This step needs to be done to determine whether the compounds of interest worthy to be synthesized or not. This chronological process will increase the efficiency of drug discovery effort. The result showed that all four compounds possessed better rerank score compared to reference compound. Rerank scores produced by Molegro Virtual Docker (MVD 5.0) represent the affinity of the ligand to the receptor, which are show the strength of ligand-receptor interacton. The smaller the value means the better the ligand-receptor affinity. In the synthesis step, allylthiourea was reacted with benzoylchloride analogs via nucleophilic substitution (benzoylation). The primary amine group of allylthiourea took the role as a nucleophile, and attacked electrophilic carbon of carbonyl group of benzoylchloride analogs. Tetrahydrofuran (THF) was chosen as the solvent for the reason of reactants solubility and the easiness to be evaporated at the later step. Dropwise technique performed on an ice water bath was done to slower the reaction, regarding the high reactivity of benzoylchloride, so that the level of benzoic acid side product can be minimized. Trietylamine base $\left(\mathrm{Et}_{3} \mathrm{~N}\right)$ acted as a nucleophilic reaction catalyst. $\mathrm{Et}_{3} \mathrm{~N}$ base neutralizes the protons produced during benzoylation reaction. ${ }^{18}$ The mixture then refluxed on a hotplate, resulted in appearance of new spot on thin layer chromatography. The new spot indicated the formation of the product compound. Saturated sodium carbonate solution was used to clean and solidify the oily products. After the recrystallization process using methanol as solvent, the products were weighed. The rendemen of all four synthesized compound were relatively not satisfying, especially for the compounds that contain halogen moiety. The problem can be lies on the presence of chlorine atom, which carries steric hindrance issue to the nucleophilic substitution reaction. The presence of large atom such as chlorine obstruct the nucleophile to attack the positive center in the carbonyl group of the benzoylchloride compounds. The IR spectra for all of the final products showed a strong absorbtion band at $1547-1556 \mathrm{~cm}^{-1}$ corresponding to the amide carbonyl group $(-\mathrm{C}=\mathrm{O}-\mathrm{NH})$. The appearance of this band confirmed the occurrence of benzoylation on allylthiourea. It also showed sharp strong absorbtion at 1664-1692 $\mathrm{cm}^{-1}$ corresponding to vinylic double bond, and a broad band at $3459-3466 \mathrm{~cm}^{-1}$ corresponding to the $-\mathrm{OH}$ iminol, the tautomeric forms of amide. ${ }^{19}$ Mass spectra showed correct molecular ion peaks and fragmentation pattern. Isotopic patterns were utilized to confirm the presence of chloro substituent. Compounds having chlorine showed two ion peaks $\left(\mathrm{M}^{+}\right.$and $\left.\mathrm{M}^{+}=2\right)$, with abundance ratio 3:1. The NMR spectra fully comply with the structure attributed to them. ${ }^{13} \mathrm{C}-\mathrm{NMR}$ spectra showed the appearance of peak at $\delta 164.4-166.8 \mathrm{ppm}$ corresponding to the presence of new $\mathrm{O}=\mathrm{C}-\mathrm{N}$ - bond, as the product of benzoylation. Writhing test was chosen because it was a natural method and less harm the animals. This chemical induced pain method also produces a more progressive and longer duration of pain sensastion..$^{20}$ The result of pain inhibition test showed that compounds containing chlorine substituent produced better affinity compared to positive control diclofenac sodium. The presence of electron withdrawing substituent on the aromatic ring (i.e., chlorine) seemed to strengthen the analgesic activity of the compounds. ${ }^{21,22}$ Halogen group can produce beneficial characteristic to the drug molecule, as they possess obstructive effect which slow down the metabolism process on the drug molecule. This protecting mechanism affects on the longer duration of drug activity. The pain inhibition test results are parallel to the results of in silico study. Therefore the inhibition of COX-2 can be proposed as the mechanism involved at the pain inhibition activity of 1-allyl-3-benzoylthiourea analogs.

\section{CONCLUSION}

From these data we have obtained, we concluded that the analogs of 1-allyl-3-benzoylthiourea can be synthesized via benzoylation on allylthiourea reactant, the reaction can be done by modified SchottenBaumann method. However, other approaches might be considered to overcome the rendemen issue. The presence of chloro substituent, an electron withdrawing group, found to enhance the analgesic activity of the synthesized compounds. This early finding on 1-ally-3-benzoyllthiourea analogs is interesting and necessary to be developed further.

\section{REFERENCES}

1. Hinz B, Brune K. Antipyretic Analgesic: Non-Steroidal Anti-inflammatory Drugs, Selective COX-2 Inhibitors, Paracetamol and Pyrazolinones. In Analgesia; Stein, C., Ed.; Springer Berlin Heidelberg: Germany. 2006:66-87

2. Willette RE. Wilson and Gisvold's Textbook of Organic Medicinal and Pharmaceutical Chemistry, $11^{\text {th }}$ ed; Lippincott Williams \& Wilkins: Philadelphia, USA. 2004:731-3.

3. Kissin I. The Development of New Analgesics Over the Past 50 Years: A Lack of Real Breakthrough Drugs. Anesth Analg. 2010;110(3):780-9.

4. Woolf CJ. Overcoming obstacles to developing new analgesics. Nat Med. 2010;16(11):1241-7.

5. Castellsague J, Riera-Guardia N, Calingaert B, Varas-Lorenzo C, et al. Individual NSAIDs and Upper Gastrointestinal Complications: A Systematic Review and Meta-Analysis of Observational Studies (the SOS Project). Drug Safety. 2012;35(12):1127-46.

6. Ofman JJ, MacLean CH, Straus WL, et al. A Metaanalysis of Severe Upper Gastrointestinal Complications of Nonsteroidal Anti-inflammatory Drugs. J Rheumatol. 2002;29(4):804-12.

7. Lenzer J. FDA Advisers Warn: COX 2 Inhibitors Increase Risk of Heart Attack and Stroke. BMJ. 2005;330(7489):440.

8. Benyamin R, Trescot AM, Datta S, et al. Opioid Complications and Side Effects. Pain Physician. 2008;11(2):S105-S20.

9. Wardakhan WW, Abdel-Salam OME, Elmegeed GA. Screening for Antidepressant, Sedative and Analgesic Activities of Novel Fused Thiophene Derivatives. Acta Pharm. 2008;58(1):1-14

10. Vega-Perez JM, Perinan I, Argandona M, et al. Isoprenyl thiourea and Urea Derivatives as New Farnesyl Diphosphate Analogues: Synthesis and In Vitro Antimicrobial and Cytotoxic Activities. Eur J Med Chem. 2012;58:591-612.

11. Ghorab MM, Alsaid MS, Al-Dosary MS, Nissan YM, Sabry ASM. Design, Synthesis and Anticancer Activity of Some Novel Thioureido-Benzenesulfonamides Incorporated Biologically Active Moieties. Chem. Central J. 2016;10(19):1-13.

12. Shoaib M, Shafiullah, Ayaz, Tahir MN, Ali Shah SW. Synthesis, Characterization, Crystal Structures, Analgesic and Antioxidant Activities of Thiourea Derivatives. J Chem Soc Pak. 2016;38(3):479-86

13. Alagarsamy V, Meenab S, Ramseshu KV, Solomon VR, et al. Synthesis, Analgesic, Anti-inflammatory, Ulcerogenic Index and Antibacterial Activities of Novel 2-methylthio-3-substituted-5,6,7,8-tetrahydrobenzo(b)thieno[2,3-d]pyrimidin-4(3H)ones. Eur J Med Chem. 2006;41(11):1293-300.

14. Budiati T, Suzana, Surdijati S. Synthesis, Analgesic and Anti-inflammatory Assay of Substituted Benzoylthiourea Cmpounds. Maj Farm Ina. 2010;21(1):68-76.

15. Cannon JG. Analog Design. In Burger's Medicinal Chemistry and Drug Discovery, $6^{\text {th }}$ ed, Vol 1: Drug Discovery; Abraham, D.J., Ed., Wiley-interscience, USA. 2003;699-704.

16. Shalas AF, Siswandono, Rudyanto M. Synthesis and Structure-Activity Relationship of 1-Allyl-3-(2-Chlorobenzoyl) Thiourea as Analgesic. IJPPS. 2016;8(6):297-8.

17. Clayden J, Greeves N, Warren S. Organic Chemistry, $2^{\text {nd }}$ ed. Oxford University Press: New York, USA. 2012: 203.

18. Carey FA, Sundberg RJ. Advanced Organic Chemistry, $4^{\text {th }}$ Ed. Springer: New York, USA. 2007: 154-5

19. Balestrero RS, Forkey DM, Russel JG. ${ }^{15} \mathrm{~N}-\mathrm{NMR}$ : Iminothiol-Thioamide Tautomerism of 2-Mercaptobenzazoles and I-Methyl-2- mercaptoimidazole. Mag Reson in Chem. 1986;24(8):651-5.

20. Le Bars D, Gozariu M, Cadden SW. Animal Model of Nociception. Pharmacol Rev. 2001;53(4):598-643.

21. Jainey PJ, Bhat IK. Antitumor, Analgesic, and Anti-inflammatory Activities of Synthesized Pyrazolines. J Young Pharm. 2012;4(2):82-7.

22. Smith HJ, HywelW. Introduction to the Principles of Drug Design. John Wright and Sons Itd: Bristol, England. 1983; 216

Article History: Submission Date : 20-07-2017 ; Revised Date : 19-08-2017; Acceptance Date : 29-09-2017.

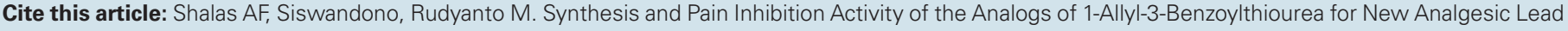
Compound Discovery. J Young Pharm. 2018;10(1):12-5 